\title{
Pemanfaatan Buku Ajar Statistik Terapan dan Aplikasi SPSS untuk Meningkatkan Kompetensi Meneliti bagi Guru IPA Tingkat SMP di Sleman, Yogyakarta
}

\section{Utilization of Applied Statistics Books and SPSS Applications to Increase Competence of Research for Science Teachers in Junior High School (SMP) in Sleman, Yogyakarta}

\author{
Eko Widodo, Dadan Rosana, Didik Setyawarno
}

Jurusan Pendidikan IPA FMIPA, FMIPA UNY, Email: eko_widodo@uny.ac.id

\begin{abstract}
Abstrak
Tujuan program pengabdian (PPM) ini adalah meningkatkan penguasaan uji statistik yang bersifat terapan dalam bidang penelitian pendidikan bagi guru IPA di Sleman, Yogyakarta dengan menggunakan buku ajar statistik terapan. Kegiatan PPM ini diperuntuk bagi guru-guru IPA di Sleman, Yogyakarta. Pelaksanaan kegiatan ini akan disatukan dengan agenda kegiatan MGMP guru IPA di Sleman, Yogyakarta yang dilakukan secara rutin. Pelatihan dilakukan di Laboratorium Komputer Jurusan Pendidikan IPA FMIPA UNY. Bentuk kegiatan PPM yang akan dilaksanakan dalam kegiatan PPM ini meliputi: tutorial, praktik, tugas terstruktur, dan konsultasi tugas. Pelatihan ini diikuti oleh 10 peserta dari target 20 peserta dari guru-guru IPA SMP di Sleman, Yogyakarta. Hasil kegiatan pelatihan ini yaitu guru memiliki pemahaman dasar dalam uji statistik untuk penelitian pendidikan dan mampu memiliki kemampuan menggunakan aplikasi SPSS dalam uji statistik.
\end{abstract}

Kata kunci: Bahan Ajar Statistik, Penelitian, Guru IPA

\begin{abstract}
The purpose of this program of dedication (PPM) is to increase the mastery of statistical tests that are applied in the field of educational research for science teachers in Sleman, Yogyakarta by using textbooks of applied statistics. This PPM activity is intended for science teachers in Sleman, Yogyakarta. Implementation of this activity will be incorporated with the agenda of MGMP science teacher activity in Sleman, Yogyakarta, conducted regularly. The training was conducted at the Laboratory of Computer Science Department IPA FMIPA UNY. The forms of PPM activities to be implemented in this PPM activity include: tutorials, practices, structured assignments, and consulting assignments. The training was attended by 10 participants from the target of 20 participants from SMP science teachers in Sleman, Yogyakarta. The result of this training activity is that teachers have basic understanding in statistical test for educational research and able to have ability to use SPSS application in statistical test.
\end{abstract}

Keywords: Teaching Material Statistics, Research, Science Teachers.

\section{PENDAHULUAN}

UU No. 14 Tahun 2005 tentang Guru dan Dosen menyatakan bahwa guru mempunyai kedudukan sebagai tenaga profesional. Salah satu indikator guru yang professional adalah kemampuan dalam melakukan penelitian dan publikasi artikel hasil penelitiannya. Berdasarkan Permen PAN-RB Nomor 16 Tahun 2009 Bab VII Pasal 16 ayat 2 terdapat tuntutan bagi guru untuk melakukan publikasi ilmiah atau karya inovatif sebagai syarat untuk kenaikan jabatan/pangkat. Publikasi ilmiah atau karya inovatif tersebut dapat dikembangkan salah satunya dengan penelitian. Data yang berasal dari prosiding seminar nasional pendidikan IPA di FMIPA UNY sampai tahun 2016 artikel ilmiah dari guru IPA SMP masih relatif sedikit.

Penguasaan statistik terapan dalam bidang penelitian pendidikan merupakan salah satu faktor untuk meningkatkan 
kompetensi guru IPA untuk melakukan penelitian. Analisis data hasil penelitian sangat membutuhkan penguasaan statistik terlebih penggunaan SPSS. Penelitian sederhana atau selevel penelitian eksperimen juga membutuhkan analisis statistik misal uji beda, uji korelasi, uji regresi, uji normalitas, dan lain sebagainya sesuai dengan variabel yang diteliti. Dalam dunia penelitian dan pendidikan, kebutuhan untuk mengumpulkan dan menginterpretasi atau menafsirkan data sudah menjadi kebutuhan yang tidak dapat dipisahkan. Berbagai program pengabdian kepada masyarakat (PPM) telah dilakukan oleh berbagai perguruan tinggi, namun PPM yang bermuatan penguasaan statistik untuk mendukung kompetensi meneliti masih perlu diintensifkan untuk meningkatkan kompetensi guru di bidang penelitian kelas. Dengan demikian hal tersebut dapat meningkatkan jumlah artikel ilmiah atau penelitian.

Jumlah artikel ilmiah yang relatif masih sedikit tersebut tentunya banyak faktor penyebabnya baik dari internal maupun eksternal guru. Hasil penelitian yang dilakukan oleh Zuhdan K.P (2012) dalam mengembangkan KKNI pendidikan fisika menyatakan bahwa kompetensi guru masih bervariasi sehingga diperlukan standar kelulusan bagi calon guru saat ini. Faktor internal yang menyebakan jumlah publikasi artikel penelitian masih sedikit adalah masih rendahnya guru dalam melakukan penelitian disamping penguasaan statistik terapan bidang penelitian pendidikan. Faktor eksternal dapat berasal dari masih belum terbentuk kominitas guru yang secara rutin melakukan penelitian dan belum optimalnya pelatihan terkait dengan penelitian.

Guru merupakan kunci dalam peningkatan mutu pendidikan dasar dan menengah, dan berada di titik sentral dari setiap usaha -usaha peningkatan mutu pendidikan. Penelitian bagi guru dapat digunakan untuk meningkatkan kualitas baik proses pembelajaran maupun evaluasi pembelajaran. Perkembangan ICT yang sangat pesat di era digital ini telah melahirkan berbagai aplikasi olah data yang dapat digunakan oleh peneliti dengan prosedur yang relatif mudah. Aplikasi statsitik yang lazim digunakan oleh peneliti baik penelitian sederhana (sekedar mendeskripsikan data) maupun yang bersifat inferensial dapat diselesaikan dengan baik melalui SPSS. Disamping itu, berbagai ilmu yang telah dikembangkan oleh para tokoh pendidikan perlu disebarluaskan dikalangan pendidikan khususnya kepada guru. Salah satu yang dapat diterapkan untuk meningkatkan kompetensi guru dalam melakukan penelitian adalah pemanfaatan buku ajar statistik terapan yang disusun oleh Dadan Rosana dan Didik Setyawarno untuk penelitian bidang pendidikan dalam program pengabdian kepada masyarakat.

Buku ajar statistik terapan tersebut digunakan dalam perkuliahan statistik terapan di program studi Pendidikan IPA FMIPA UNY sejak tahun 2016. Buku ajar tersebut merupakan hasil hibah penulisan buku pada tahun 2016. Buku yang bersifat aplikatif telah diujikan dalam perkuliahan selama satu semester. Dalam hal ini, langkah awal untuk menumbuhkan minat bagi guru untuk melakukan penelitian adalah penguasaan statistik dalam pengolahan data. Materi statistik terapan yang dibutuhkan oleh guru perlu menekankan pada bagaimana pengolahan data menggunakan SPSS, STATA, dan Software pengolahan data lainnya.

Berdasarkan uraian di atas, program pengabdian kepada masyarakat (PPM) untuk memanfaatkan buku ajar statistik terapan perlu dilakukan dengan tujuan meningkatkan kompetensi guru melakukan penelitian. Dengan langkah tersebut diharapkan artikel ilmiah hasil penelitian guru dapat meningkat dari tahun ke tahun.

\section{SOLUSI/TEKNOLOGI}

Kegiatan PPM yang akan dilaksanakan adalah kegiatan pelatihan yang ditujukan 
bagi guru-guru IPA tingkat SMP di Sleman, Yogyakarta. Uraian dari kegiatan pelatihan meliputi:

1. penyampaian materi yang meliputi konsep dasar statistik kaitannya dengan penelitian,

2. materi panduan dasar uji statistik dalam penelitian bidang pendidikan, dan

3. praktek menggunakan aplikasi SPSS untuk uji statistik.

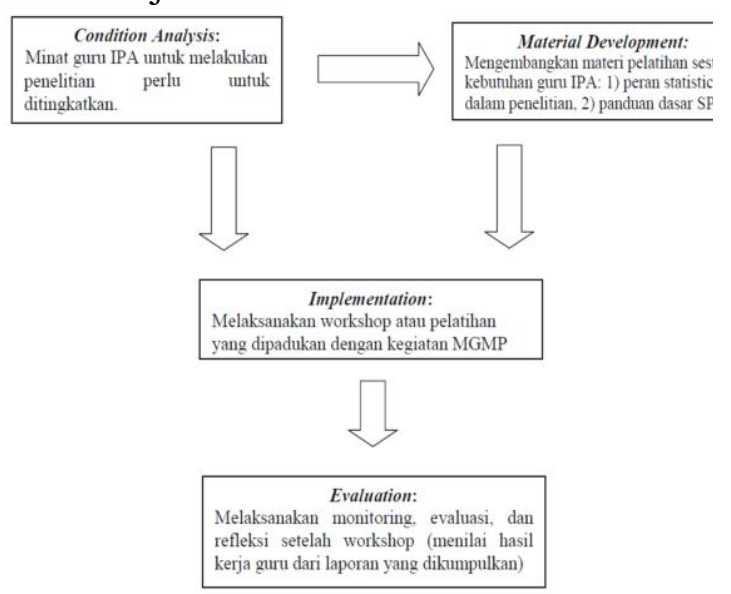

Gambar 1. Alur Pemecahan Masalah

Kegiatan PPM ini diperuntuk bagi guru-guru IPA di Sleman, Yogyakarta. Pelaksanaan kegiatan ini akan disatukan dengan agenda kegiatan MGMP guru IPA di Sleman, Yogyakarta yang dilakukan secara rutin.

Masalah penguasaan uji statistik yang belum optimal bagi guru IPA merupakan persoalan yang harus diatasi dalam rangka menumbuhkan kompetensi guru untuk melakukan penelitian. Permasalahan tersebut dapat diselesaikan dengan dilakukan beberapa hal sebagai berikut:

1. Memberikan pemahaman secara utuh tentang keterkaitan antara statistik dengan penelitian.

2. Memberikan pelatihan konsep dasar statistik berikut aplikasi pengujiannya dalam berbagai jenis penelitian.

3. Memberikan pengalaman langsung bagi guru untuk menggunakan aplikasi SPSS untuk uji statistik.

Ketiga kegiatan tersebut dapat dilaksanakan dengan baik dengan berbagai pertimbangan yaitu penggunaan waktu jauh lebih efisien dan dapat dipraktekkan langsung di sekolah setelah pelatihan selesai dilaksanakan. Pada saat pelaksanaan, monitoring, evaluasi dan refleksi dilaksanakan terus menerus untuk mencapai hasil kegiatan yang maksimal. Secara rinci, alur pemecahan masalah digambarkan dengan diagram berikut ini.

Kegiatan PPM dilaksanakan dengan cara tutorial (Tatap Muka), workshop, penugasan terstruktur, dan konsultasi sebagai berikut.

1. Tutorial dan workshop: materi 1 adalah uji statistik dalam penelitian Pendidikan.

2. Tutorial dan workshop: materi 2 adalah aplikasi SPSS untuk uji statistik.

3. Tugas Terstruktur:

a. Melakukan uji statistik prasyarat analisis.

b. Melakukan uji beda atau uji t dengan aplikasi SPSS.

4. Konsultasi Tugas: konsultasi dilakukan via email/HP, khususnya bagi peserta pelatihan yang mengalami kesulitan dalam menyelesaian tugas terstruktur.

Evaluasi dan refleksi kegiatan pelatihan dilakukan secara menyeluruh baik sebelum maupun setelah program selesai. Tim PPM akan melihat kondisi awal guru tentang penelitian dan uji statistik yang telah mereka dengan menggunakan angket. Demikian juga untuk mengetahui tanggapan peserta pelatihan terkait dengan kegiatan yang telah dilaksanakan oleh Tim PPM. Penguasaan guru dalam menggunakan aplikasi SPSS dilihat ketika sesi praktik dan laporan tugas yang telah dikumpulkan. Selain itu, sertifikat hasil pelatihan akan diberikan ketika laporan sudah dikumpulkan ke Tim PPM dengan kategori cukup, baik, dan sangat baik.

\section{HASIL DAN DISKUSI}

PPM yang telah dilaksanakan ini merupakan PPM berbasis pelatihan yang bersifat aplikatif bagi Guru SMP di Sleman. Sebelum PPM dilaksanakan, TIM 
PPM melakukan koordinasi persiapan segala sesuatu yang dibutuhkan untuk kegiatan baik sebelum maupun saat pelaksanaan. Persiapan yang dilakukan oleh Tim PPM mencakup aspek akademik, administrasi, dan non-akademik. Aspek akademik yang disiapakan meliputi: pemateri utama, makalah/materi dalam bentuk ppt, komputer (bagi peserta pelatihan disediakan komputer di laboratorium komputer IPA), dan lembar penilaian/monitoring. Persiapan administrasi mencakup lembar presensi, keperluan pertanggungjawaban keuangan, dan sertifikat untuk peserta. Persiapan nonakademik mencakup ruang, LCD, dan konsumsi. Tim PPM dalam hal ini terdiri dari dosen, mahasiswa, dan laboran Lab. IPA.

Sebelum pelatihan diakhiri, Tim PPM meminta tanggapan dari peserta pelatihan secara lisan dan lembar isian terhadap kegiatan pelatihan yang telah dilaksanakan. Secara ringkas hasil tanggapan guru dapat disimpulkan baik dan mendukung kompetensi guru untuk melakukan penelitian di kelas baik dengan model eksperimen maupun penelitian tindakan kelas. Hasil analisis lembar isian menyatakan bahwa kegiatan PPM sangat dibutuhkan oleh peserta pelatihan/ guru untuk memenuhi salah satu kewajiaban dalam kenaikan pangkat. Peserta pelatihan menyatakan terbantu dengan adanya kegiatan pelatihan ini. Hasil analisis tugas terkait uji statistik dengan aplikasi SPSS menunjukkan bahwa peserta mampu menggunakan dengan baik dan membaca hasil analisis dengan baik. Harapan peserta pelatihan adalah kegiatan ini bisa dilanjutkan di waktu lain dengan tema yang serupa terkait dengan pengembangan penelitian di sekolah.

Pelaksanaan PPM tidak terlepas dari factor pendukung dan pengambat. Faktor Pendukung terlaksananya PPM yaitu:

a. Jumlah komputer lebih dari cukup, sehingga semua satu peserta menggunakan satu komputer. b. Motivasi peserta untuk menjadi guru IPA yang professional yang ditandai dengan banyak peserta yang bertanya selama pelatihan.

c. Kepakaran tim pengabdi sesuai dengan program pelatihan yang diselenggarakan.

Sedangkan faktor Penghambat yaitu:

d. Padatnya jadwal guru di sekolah, sehingga susah menentukan jadwal pelatihan.

e. Hari pelaksanaan PPM bersamaan dengan agenda Dinas Pendidikan sedingga peserta yang mengikuti pelatihan di bawah target.

Kemampuan dan ketrampilan guru

IPA dalam melakukan penelitian di kelas saat ini perlu didukung oleh penguasaan uji statistik yang memadahi. Penguasaan tersebut menjadi dasar untuk penyusunan karya ilmiah bagi guru. Berdasar faktafakta tersebut di atas maka direkomendasikan beberapa hal sebagai berikut.

1. Kegiatan PPM dilakukan secara rutin dilaksanakan untuk topik yang berbeda dengan diperluas sasaran dan wilayahnya.

2. Perlu dilakukan pelatihan pengelolaan laboratorium IPA

3. Pelatihan dengan memanfaatan ICT untuk pembelajaran

4. Pelatihan bedah soal/ kisi-kisi soal Olimpiade Sains SMP.

5. Perlu diintensifkan kemitraan antara FMIPA UNY dengan Pemda Propinsi atau Kabupaten/Kota dalam program pre-service, in-service maupun onservice training, sehingga akan terbentuk mutual relationship antar institusi yang terlibat.

\section{KESIMPULAN}

Berdasarkan uraian sebelumnya dapat disimpulkan bahwa Program Pengabdian (PPM) telah terlaksana dengan hasil yang baik. Hasil penilaian melalui lisan, lembar isian, serrta hasil pengumpulan tugas 
terstruktur dari guru-guru peserta pelatihan, dapat disimpulkan bahwa PPM dengan yang dilakukan melalui pemanfaatan buku ajar statistik terapan dan dapat meningkatkan kompetensi bagi guru IPA dalam analisis data hasil penelitian bidang pendidikan. Materi yang di susun oleh Tim mudah dipahami oleh peserta pelatihan dan berguna untuk meningkatkan kompetensi guru dalam melakukan penelitian pendidikan.

\section{UCAPAN TERIMA KASIH}

Tim PPM mengucapkan terima kasih kepada Fakultas Matematika dan Ilmu Pengetahuan Alam yang telah mendukung pelaksanaan PPM melalui dana DIPA UNY anggaran tahun 2017

\section{PUSTAKA}

Catur Hari Wibowo. 2015. Tesis: Problematika Profesi Guru dan Solusinya bagi Peningkatan Kualitas Pendidikan di MTS Negeri Nguntoronadi Kabupaten Wonogiri. Surakarta: PPs IAIN Surakarta.

Dadan Rosana dan Didik Setyawarno. 2016. Statistik Terapan untuk Penelitian Bidang Pendidikan. Yogyakarta: FMIPA UNY.
Intan Pulungan. 2015. Peningkatan Kemampuan Guru dalam Melakukan Penelitian Tindakan Kelas Melalui Implementasi Diklat. Di download di http://sumut.kemenag.go.id/ tanggal 17 Maret 2017.

Maria Ungin. 2013. Studi tentang Kualitas Tenaga Pengajar (Guru) pada SMP N 17 Sendawar Kabupaten Kutai Barat. E-Journal Administrasi Negara, 2013, 1 (1): 97-108.

Surya Dharma. 2008. Pendekatan, Jenis, dan Metode Penelitian Pendidikan. Jakarta: Direktur Tenaga Kependidikan Ditjen PMPTK.

Sugiyono. 2008. Metode Penelitian Pendidikan. Bandung: Alfabeta.

Samtono. Guru sebagai Key Person dalam Uaya Peningkatan Mutu Pendidikan di Sekolah. Yeti Nurizzati. 2012. Peranan Statistika dalam Penelitian Sosial. Jurnal Edueksos Vol I No 1, Januari-Juni 2012.

Zuhdan Kun Prasetyo, Senam, Slamet Suyanto. 2012. Laporan Penelitian: Pengembangan Kerangka Kualifikasi Nasional Indonesia (KKNI) Level 6 Pendidikan Biologi, Pendidikan Fisika, dan Pendidikan Kimia. Yogyakarta: PPs UNY. 